\title{
Fatigue, sleepiness, perceived stress and physical activity in postpartum mothers according to the infants' feeding method. A pilot study
} Poziom zmęczenia, senności, odczuwanego stresu i aktywności fizycznej u matek karmiących w zależności od metody karmienia. Badanie pilotażowe

\author{
${ }^{1}$ Specialist Medical Practice, Poznań, Poland \\ ${ }^{2}$ Department of Physiology, Poznan University of Medical Sciences, Poznań, Poland \\ ${ }^{3}$ Students'Science Club, Collegium Medicum, University of Zielona Góra, Zielona Góra, Poland \\ ${ }^{4}$ Department of Applied and Clinical Physiology, Collegium Medicum, University of Zielona Góra, Zielona Góra, Poland \\ Correspondence: Magdalena Gibas-Dorna, Department of Applied and Clinical Physiology, Collegium Medicum, University of Zielona Góra, Zyty 28, 65-046 Zielona Góra, Poland, \\ e-mail:m.gibas-dorna@cm.uz.zgora.pl
}

\section{ORCID iDs}

1. Jolanta Nurek (D)htps://orid.org/0000-0003-0649-9044

2. Beata Buraczyńska-Andrzejewska (D)https://orcid.org/0000-0002-8928-9482

3. Iga Kolasa iDhttps://orcid.org/0000-0002-8535-0485

4. Bartłomiej Czyżniewski iDhttps://orcid.org/0000-0001-6208-0227

5. Magdalena Gibas-Dorna (iDhttps://orcid.org/0000-0002-8408-2829

\begin{abstract}
Aim of the study: Early motherhood is the time when the female body must cope with sleep deprivation, fatigue, and stress associated with increased responsibilities following the birth of the baby. The aim of this paper was to investigate the psychological wellbeing and physical activity of healthy mothers in the first months postpartum according to the infants' feeding method. Materials and methods: 24 healthy exclusively breastfeeding and 13 healthy exclusively formula-feeding mothers participated in this study. The results were based on the standardised scales: Fatigue Severity Scale (FSS), Epworth Sleepiness Scale (ESS), Perceived Stress Scale (PSS), and Kaiser Physical Activity Survey (KPAS). Results: When comparing data between the two studied groups, we found that breastfeeding women reported lower levels of sleepiness $(p=0.011)$ and fatigue ( $p=0.0006)$ than formula-feeding mothers. Perceived stress and physical activity did not differ between the groups. Positive correlation between PSS and FSS was found $(r=0.62, p<0.005)$ in the group of breastfeeding mothers. Conclusions: 1) In breastfeeding mothers, fatigue and perceived stress reinforce each other. This relationship serves as an alarm signal to provide nursing mothers with optimal care in order to prevent them from stopping breastfeeding. 2) In a healthy population of mothers from 3 to 6 months postpartum, exclusively breastfeeding women are observed to have lower fatigue and sleepiness levels compared to those who decided to feed their children with formula only. These conclusions may be an additional source of information for the promotion of breastfeeding.
\end{abstract}

Keywords: breastfeeding, formula feeding, stress, fatigue, sleepiness, physical activity

Streszczenie

Cel: Wczesne macierzyństwo jest okresem w życiu kobiety, w którym organizm musi sprostać niedoborom snu, zmęczeniu oraz stresowi związanym z opieką nad dzieckiem. Celem pracy było zbadanie samopoczucia i dobrostanu psychicznego zdrowych matek karmiących w pierwszych miesiącach życia dziecka w zależności od metody karmienia. Materiał i metoda: W badaniu wzięły udział 24 kobiety karmiące wyłącznie piersią oraz 13 kobiet karmiących wyłącznie sztucznie. Wykorzystując standaryzowane skale: stopnia zmęczenia (Fatigue Severity Scale, FSS), senności Epworth (Epworth Sleepiness Scale, ESS), odczuwanego stresu (Perceived Stress Scale, PSS) oraz aktywności fizycznej (Kaiser Physical Activity Survey, KPAS), pozyskano dane, które porównano pomiędzy badanymi grupami. Zbadano też zależności pomiędzy użytymi skalami w obu grupach respondentek. Wyniki: Wykazano, że kobiety karmiące piersią odczuwają mniejszą senność $(p=0,011)$ oraz zmęczenie $(p=0,0006)$ w porównaniu z karmiącymi sztucznie, podczas gdy poczucie stresu oraz aktywność fizyczna związana z obowiązkami domowymi nie różnią się pomiędzy grupami. U matek karmiących piersią istnieje pozytywna 
korelacja pomiędzy wynikami w skalach PSS i FSS $(r=0,62, p<0,005)$. Wnioski: 1$)$ U matek karmiących piersią zmęczenie i odczuwany stres wzajemnie się potęgują. Zależność ta stanowi sygnał alarmowy do podjęcia optymalnej opieki nad matką karmiącą, po to by zapobiec podjęciu decyzji o zaprzestaniu karmienia piersią. 2) W zdrowej populacji matek karmiących w okresie 3-6 miesięcy od porodu u kobiet karmiących wyłącznie piersią obserwuje się mniejszy stopień zmęczenia i senności w porównaniu z matkami, które podjęły decyzję o wyłącznym karmieniu mlekiem modyfikowanym. Wskazane wnioski mogą stanowić dodatkowe źródło informacji wykorzystywanej do promocji karmienia naturalnego.

Słowa kluczowe: karmienie piersią, karmienie sztuczne, stres, zmęczenie, senność, aktywność fizyczna

\section{INTRODUCTION}

$\mathrm{C}$ hildbirth and nursing are perceived as an unique and difficult experience for every woman. Pregnancy and lactation clearly have an impact on the whole female body with health consequences in the years to come. Literature data show that women experience chronic fatigue and stress to a particularly large extent in early motherhood, which has a direct impact on their mental and physical health, especially on their mood, motivation for daily activities and social interactions ${ }^{(1,2)}$. Chronic fatigue is considered as one of the fundamental risk factors for postpartum depression with all the consequences for the mother and the child. It is estimated that during the first 2 years after delivery, $10-20 \%$ experience depressive symptoms and as many as $43-64 \%$ have symptoms of chronic fatigue ${ }^{(3)}$. Apart from the huge energetic expenditure of lactation, the causes of chronic fatigue are primarily sleep deficit and poorer sleep quality associated with nocturnal awakenings. Interestingly enough, a comparison of various neonate and infant feeding methods demonstrated that breastfeeding mothers sleep longer (by 40 minutes on average) than formula-feeding mothers ${ }^{(4)}$. In addition, compared to formula feeding, breastfeeding is associated with a higher number of non-rapid eye movement stage 3 (NREM3) and lower number of rapid eye movement (REM) stages of sleep ${ }^{(5)}$. Other studies show that apart from subjective improvement of sleep quality, breastfeeding has a beneficial impact on the mood and indicators of induced stress in mothers (blood pressure, heart rate, and serum levels of adrenocorticotropic hormone and cortisol $)^{(6,7)}$.

When natural feeding is promoted as the optimal method of feeding a newborn or an infant, usually the benefits for the child are emphasised, whereas the mother's wellbeing is without a doubt the basis for providing appropriate care to the child, including nutrition. Due to differences regarding cultural and socioeconomic factors, and women's quality of life, it is important for research to take into account various study models in populations of many countries.

The present study aimed to investigate the mental wellbeing of healthy mothers during the first months of their child's life depending on the method of feeding (exclusive breastfeeding vs exclusive formula feeding) and to evaluate the relationship between fatigue, sleepiness, level of perceived stress and physical activity of postpartum mothers. To this end, the study em-

\section{MATERIALS AND METHODS}

\section{Study group}

Subjects were enrolled during routine follow-up visits of mothers with children at primary care clinics: NZOZ Certus (Poznań, Poland), Pro Familia (Koziegłowy, Poland) and Salvita (Poznań) in 2017/2018. All participants provided their written consent for participation in the study. The study was approved by the Ethics Committee at the Poznan University of Medical Sciences (Ref. No.: KB-1096/16, annex Ref. No.: KB-246/19). Inclusion criteria were the following: healthy mothers who exclusively breastfed at 3-6 months of lactation, healthy mothers who exclusively formula-fed by choice (for no significant medical reason) at 3-6 months postpartum, natural labour. Exclusion criteria comprised: caesarean section or assisted delivery, perinatal complications, chronic diseases (diabetes, arterial hypertension, dyslipidaemia, inflammatory and autoimmune diseases, cancer), acute infection within 4 weeks before enrolment. Inclusion criteria were met by $30 \mathrm{ex}-$ clusively breastfeeding mothers and 20 exclusively formula-feeding mothers, with the formula-feeding women being a control group at the same time. Ultimately, 24 women who exclusively breastfed at 3-6 months of lactation, and 13 women who exclusively formula-fed by choice (for no significant medical reason) at 3-6 months counting from delivery took part in the study. The enrolment process is presented in Fig. 1.

Exclusive breastfeeding was defined based on World Health Organization (WHO) standards as feeding a child only with breast milk from birth without giving it water or other fluids except for when oral pharmacotherapy is required. Exclusive formula feeding was defined as feeding the child with infant formulas from the time of birth without giving it breast milk.

\section{Research tools}

Data were obtained using an originally developed survey for gathering study group characteristics and standardised scales regarding levels of fatigue, sleepiness, perceived stress and physical activity of postpartum mothers:

1. Fatigue Severity Scale (FSS) - one of the most commonly used standardised scale consisting of 9 questions 


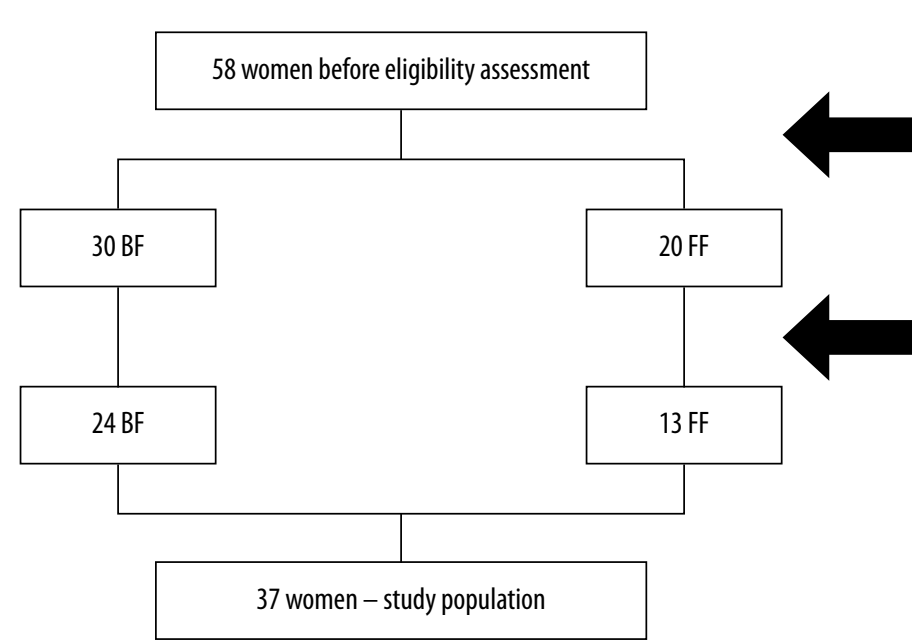

Fig. 1. Enrolment process

to assess the impact of fatigue on activity, motivation, work and family life. It was introduced and described by Krupp et al. ${ }^{(8)}$. The final score is an arithmetic mean of the scores on all items; the higher the final score, the higher the fatigue. A cut-off value of 4 was adopted based on a paper by Valko et al. ${ }^{(9)}$.

2. Epworth Sleepiness Scale (ESS) - the most commonly used scale for daytime sleepiness assessment. The scale rates the probability of falling asleep during 8 daily activities; the higher the score, the higher the sleepiness. The scale was introduced and described by Johns ${ }^{(10)}$. ESS score interpretation:

- 0-10 points - normal score;

- 11-14 points - mild sleepiness;

- 15-18 points - moderate sleepiness;

- over 18 points - severe sleepiness, medical consultation required.

3. Perceived Stress Scale (PSS) - a scale used to assess to what extent 10 life situations affected the respondents' perception and behaviour in the last month; the higher the score, the higher the level of perceived stress. The scale was introduced and described by Cohen et al. ${ }^{(11)}$.

4. Kaiser Physical Activity Survey (KPAS) measuring physical activity of women. The scale was introduced and described by Sternfeld et al. ${ }^{(12)}$. It was based on a modification proposed by Baecke et al. ${ }^{(13)}$. The scale includes 4 main sections associated with household activities and family care (child/elderly care), occupation, daily activities and exercise. The higher the total KPAS score, the higher the physical activity.

\section{Statistical analysis}

For all quantitative variables, means and standard deviations were calculated. Qualitative variables were described and percentage values were provided for their different categories. A two-sample $t$-test and the Wilcoxon test were used to compare breastfeeding and formula-feeding mothers in terms of fatigue, stress, sleepiness and physical activity.
Exclusion criteria:

- caesarean or assisted delivery

- perinatal complications

- chronic diseases

- acute infection within 4 weeks before enrolment

- $2 \mathrm{BF}$ and $3 \mathrm{FF}$ did not complete the study due to infection

- $2 \mathrm{BF}$ and $2 \mathrm{FF}$ did not complete the survey

- $1 \mathrm{BF}$ completed only a part of the survey

- $1 \mathrm{BF}$ and $2 \mathrm{FF}$ did not report back to the clinic without providing the reason

BF - breastfeeding mothers; FF - formula-feeding mothers.
The assumption of normality and homogeneity of variance were checked by the Shapiro-Wilk and Fisher's tests.

The Fisher's test was used to compare breastfeeding mothers and formula-feeding mothers in terms of the frequency of daytime and night-time feeding and of getting up to take care of the child.

Relationships between the following variables: fatigue, stress, sleepiness and physical activity were determined using Pearson's correlation coefficient. For all tests the $\alpha$ significance level of 0.05 was adopted. The calculations and figures were made using the $\mathrm{R}$ v4.0.3 software.

\section{RESULTS}

The basic subjects' variables included age, body weight and height, weight gain/loss in relation to the time before pregnancy, marital status (indicated by terms used in official statistics: married, single, partner, divorced, widow), educational level (primary, secondary, tertiary), employment (employed, employed but currently on a leave, unemployed, non-university student, university student, a person on an incapacity benefit), and night-time and daytime feeding frequency. Only complete data provided by the respondents were included in the analysis. The data collected are presented in Tab. 1 .

The data included in Tab. 1 were compared between the two study groups (breastfeeding vs. formula-feeding mothers). The study groups differed significantly in terms of weight gain (weight before pregnancy vs current weight; $p=0.0218)$, marital status $(p=0.0038)$ and frequency of daytime feeding ( $p=0.0491$; incomplete data, not included in the table). Other subject characteristics did not display any statistically significant differences $(p>0.05)$. In both groups, more than $80 \%$ of women were on maternity or child care leave.

The collected survey data were used to compare the two groups with regard to scores on standardised scales (ESS, FFS, KPAS and PSS). The comparative analysis is presented in Fig. 2. Values with $p<0.05$ were considered statistically significant. 


\begin{tabular}{|c|c|c|c|c|c|c|c|c|c|}
\hline $\begin{array}{l}\text { Feeding } \\
\text { method }\end{array}$ & $\begin{array}{c}\text { Age } \\
\text { [years (\%)] }\end{array}$ & $\begin{array}{c}\text { Body weight } \\
\text { [kg] }\end{array}$ & $\begin{array}{c}\text { BMI } \\
{\left[\mathbf{k g} / \mathbf{m}^{2}\right]}\end{array}$ & $\begin{array}{c}\text { Weight } \\
\text { gain/loss } \\
\text { [kg] }\end{array}$ & $\begin{array}{c}\text { Marital status } \\
{[\%]}\end{array}$ & $\begin{array}{c}\text { Education } \\
{[\%]}\end{array}$ & $\begin{array}{c}\text { Employment } \\
{[\%]}\end{array}$ & $\begin{array}{c}\begin{array}{c}\text { Number } \\
\text { of } \\
\text { deliveries } \\
{[\%]}\end{array} \\
\end{array}$ & $\begin{array}{c}\text { Frequency } \\
\text { of night-time } \\
\text { feeding } \\
{[\%]}\end{array}$ \\
\hline $\begin{array}{l}\text { Breastfeeding } \\
\text { mothers } \\
(n=24)\end{array}$ & $\begin{array}{c}20-25(4.2) \\
26-30(37.5) \\
31-35(33.3) \\
36-40(25)\end{array}$ & $67.78 \pm 11.40$ & $24.53 \pm 4.06$ & $-0.70 \pm 7.23$ & $\begin{array}{c}\text { Married - 87.5 } \\
\text { Single }-4.2 \\
\text { Divorced -0 } \\
\text { Partner - 8.3 }\end{array}$ & $\begin{array}{c}\text { Secondary }-33.3 \\
\text { Tertiary }-66.7\end{array}$ & $\begin{array}{c}\text { Employed - 0 } \\
\text { On a leave - 87.5 } \\
\text { Unemployed - } 12.5\end{array}$ & $\begin{array}{c}1-37.5 \\
>1-62.5\end{array}$ & $\begin{array}{c}1-9.1 \\
2-3-68.2 \\
4-5-13.6 \\
\geq 6-9.1\end{array}$ \\
\hline $\begin{array}{l}\text { Formula-feeding } \\
\text { mothers } \\
(n=13)\end{array}$ & \begin{tabular}{|c|}
$20-25(7.6)$ \\
$26-30(46.2)$ \\
$31-35(23.1)$ \\
$36-40(23.1)$
\end{tabular} & $61.85 \pm 4.72$ & $21.91 \pm 1.62$ & $+3.00 \pm 2.65$ & $\begin{array}{c}\text { Married - } 38.4 \\
\text { Single - } 7.7 \\
\text { Divorced - 7.7 } \\
\text { Partner - } 46.2\end{array}$ & $\begin{array}{c}\text { Secondary }-53.9 \\
\text { Tertiary }-46.1\end{array}$ & $\begin{array}{l}\text { Employed }-15.4 \\
\text { On a leave }-84.6 \\
\text { Unemployed -0 }\end{array}$ & $\begin{array}{c}1-61.5 \\
>1-38.5\end{array}$ & $\begin{array}{c}1-0 \\
2-3-61.5 \\
4-5-38.5 \\
\geq 6-0\end{array}$ \\
\hline $\begin{array}{c}p \text { values } \\
\text { for group } \\
\text { comparisons }\end{array}$ & 0.9533 & 0.1249 & 0.0867 & $0.0218^{*}$ & $0.0038^{* *}$ & 0.3003 & 0.0966 & 0.1881 & 0.3398 \\
\hline
\end{tabular}

Tab. 1. Descriptive characteristics of the study subjects

Pearson's correlation coefficient was used to determine the relationships between the following variables: fatigue, stress, sleepiness and physical activity in the two study groups of women. A $p$ value of $<0.05$ was considered statistically significant. The results are presented in Tab. 2.

\section{DISCUSSION}

During the postpartum period, a woman has to cope with a huge physical and mental effort. Right after delivery her organism is exhausted and the fatigue can last for months due to lactation and infant care ${ }^{(14)}$. Literature data and WHO standards indicate that breastfeeding is the most recommended form of feeding infants and neonates ${ }^{(15)}$. WHO guidelines show a clear benefit from exclusive breastfeeding for the first 6 months of life with continued breastfeeding up to 2 years of age or beyond, although WHO-recommended breastfeeding practices are mainly focused on advantages for a child ${ }^{(16)}$. Both breastfeeding and formula feeding mothers are subjected to chronic stress, which is directly associated with accumulated effects of sleep deprivation and a sense of responsibility for the child's health and life.
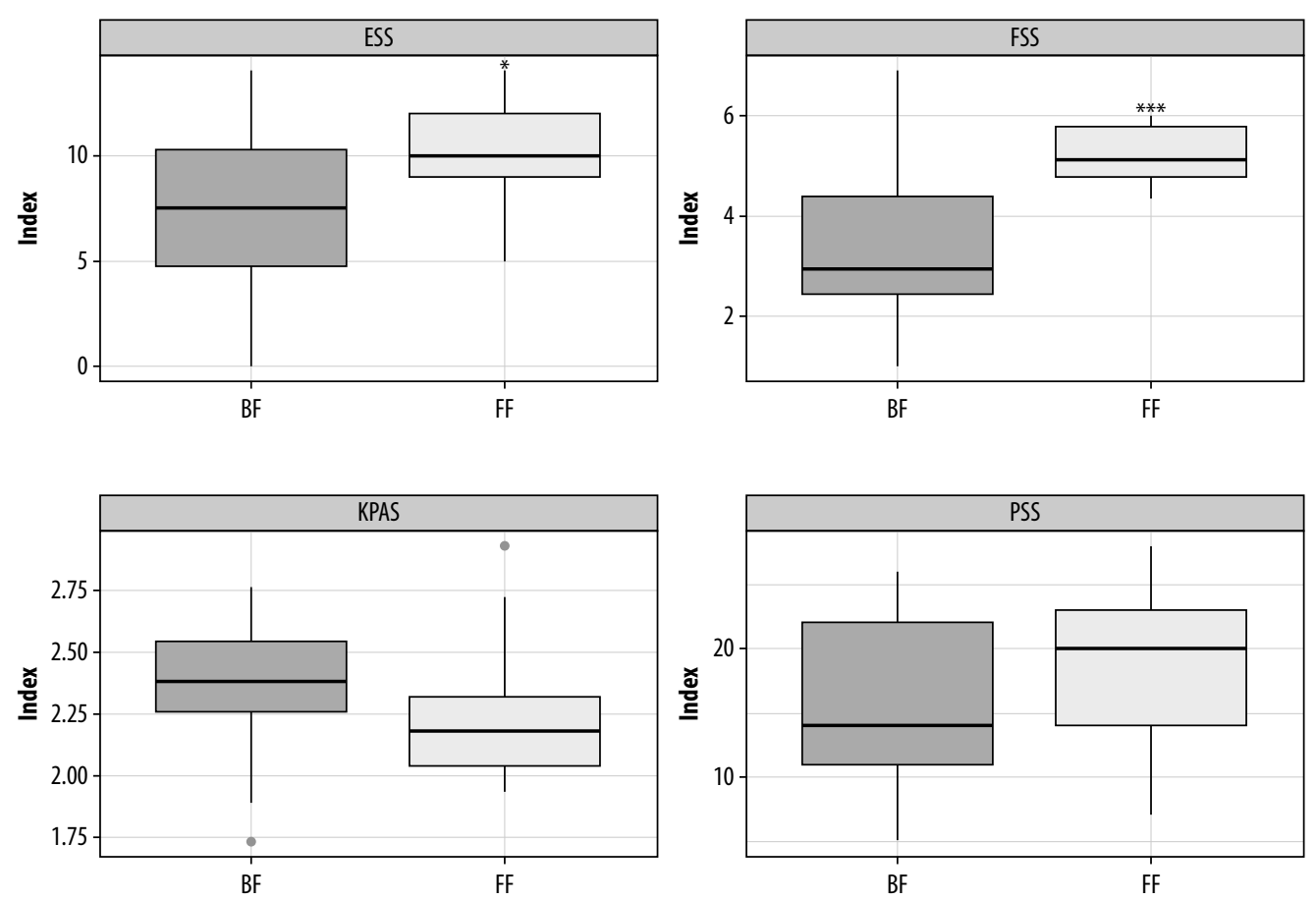

BF - breastfeeding mothers; FF - formula-feeding mothers; ESS - Epworth Sleepiness Scale; FFS - Fatigue Severity Scale; KPAS - Kaiser Physical Activity Survey; PSS - Perceived Stress Scale.

The $p$ values for the comparison of means between the study groups of women are the following: $p=0.011$ for ESS, $p=0.0006$ for FSS, $p=0.24$ for KPAS and $p=0.15$ for PSS. Values with $p<0.05$ are considered statistically significant and are marked with ${ }^{*}$ for $p<0.05$ and ${ }^{* * *}$ for $p<0.001$.

Fig. 2. Subjective daytime sleepiness, perceived fatigue and stress levels, and physical activity in the study groups of women 


\begin{tabular}{|c|c|c|c|c|c|c|c|c|c|}
\hline \multicolumn{4}{|c|}{ Breastfeeding mothers } & \multicolumn{5}{c|}{ Formula-feeding mothers } \\
\hline Scale & FFS & KPAS & PSS & Body weight & Scale & FFS & KPAS & PSS & Body weight \\
\hline ESS & 0.14 & -0.22 & 0.32 & -0.17 & ESS & -0.091 & -0.41 & 0.47 & 0.34 \\
\hline FSS & & -0.045 & $0.62^{*}$ & -0.023 & FSS & & 0.036 & 0.45 & -0.37 \\
\hline KPAS & & & -0.0028 & -0.17 & KPAS & & & -0.34 & 0.0055 \\
\hline PSS & & & & 0.11 & PSS & & & & 0.15 \\
\hline
\end{tabular}

ESS - Epworth Sleepiness Scale; FFS - Fatigue Severity Scale; KPAS - Kaiser Physical Activity Survey; PSS - Perceived Stress Scale. Values with $p<0.05$ are considered statistically significant and are marked with * for $p<0.005$.

Tab. 2. Pearson's $\mathrm{r}$ correlation coefficients in the study groups

In the present study, standardised questionnaires were used to investigate whether subjective psychological feelings differ depending on whether a mother breastfeeds or formula-feeds their child.

\section{Perceived Stress Scale (PSS)}

Regarding to subjective feeling of stress, we did not observe any statistically significant differences between formula-feeding and breastfeeding mothers. In contrast to our results, Groër demonstrated that exclusively breastfeeding women have a more positive mood and experience less psychological stress than formula-feeding women ${ }^{(6)}$. However, in that study, women were assessed at 4-6 weeks postpartum, i.e. at an early lactation phase when the levels of lactation hormones are very high in breastfeeding mothers. Considering the fact that both prolactin and oxytocin have strong anxiolytic and stress-reducing properties ${ }^{(17)}$, the significant differences found by Groër could have been the result of disproportions in the levels of these two hormones in the studied groups of women. During lactation, with time the basic levels of these hormones return to the values from before pregnancy, which is partly due to a decreased frequency of feeding the child and stimulating the mechanoreceptors of the nipple area to send a neural signal for the secretion of both prolactin and oxytocin. In the present study, the women were studied between 12 weeks and 24 weeks postpartum, i.e. in a period when the differences in lactation hormones between breastfeeding and formula-feeding mothers diminish. However, further research is necessary to elucidate the cause-and-effect relationships involved.

\section{Epworth Sleepiness Scale (ESS)}

One of the key factors affecting the functioning of a mother after birth is the appropriate amount and quality of sleep, with sleepiness being the primary symptom of sleep deprivation. The results of research on the quality and length of nocturnal sleep among nursing mothers are inconsistent. While many authors indicate that breastfeeding mothers have a better quality and longer duration of uninterrupted sleep ${ }^{(4,18,19)}$, other researchers report no differences between breastfeeding and formula-feeding mothers in that respect ${ }^{(20,21)}$. The lack of consistency in the results is probably due to heterogeneous methodology, various lengths of time elapsed from childbirth and differences in study group characteristics. In the present study, formula-feeding women were characterised by a significantly higher probability of falling asleep during 8 daily activities included in ESS. Interestingly enough, the level of sleepiness measured by ESS only slightly exceeded the norm in formula-feeding mothers, with breastfeeding mothers falling within the normal range. It is important to note that during the first 3-7 months of life the infant's sleep undergoes the fastest consolidation, biological patterns become more distinct and the infant circadian rhythm becomes more synchronised with that of the mother, particularly in breastfed children ${ }^{(22)}$. As a result, there are better conditions for a good mother's sleep. During that time, after a few months of sleeplessness and a phase of adaptation to fewer hours of night-time sleep, some mothers enter the period of a "blissful rest" in which they rate their probability of falling asleep on ESS the same as individuals who do not suffer from sleep disorders. It is worth taking note of physiological factors affecting the process of falling asleep and the quality of life after a night's sleep. Firstly, 2 processes contribute to the initiation of sleep: circadian (factor C) that depends on circadian rhythm patterns in the human body and homeostatic (factor S) which maintains a constant duration of sleep during a 24-hour period and depends on the fatigue associated with the level of daytime activity, including occupational one ${ }^{(23)}$. In the current study, there were working mothers and no unemployed women among the formula-feeding mothers, thus, the role of process $\mathrm{S}$ was more pronounced; therefore, it is possible that it contributed to a higher level of sleepiness in this group. Secondly, during early motherhood, for obvious, non-pathological reasons, sleep is transformed from a monophasic one (i.e. one long wakefulness phase and one long sleeping phase) into biphasic or polyphasic sleep with shortened night-time sleep and compensatory naps during the day. In this way, mothers adjust their sleep to their child's rhythm; some authors describe such sleep as fragmented and distinguish this phenomenon from sleep deprivation ${ }^{(24)}$.

\section{Fatigue Severity Scale (FSS)}

During early lactation, chronic fatigue in mothers is one of the most important factors causing them to stop breastfeeding. Maehara et al. compared exclusively breastfeeding and 
exclusively formula-feeding mothers and did not observe any differences in the feeling of fatigue between the two groups $^{(25)}$; however, the present authors found that between 3 and 6 months postpartum, formula-feeding mothers had a significantly higher level of fatigue than breastfeeding women. Fatigue is undoubtedly associated with stress, sleep deprivation, a large number of household and job responsibilities during the day, and a lack of available help from others (the child's father, family or members of the household). The time of participation in the study is also an important factor. At 3-6 months of age, the child's biological rhythms become better synchronised and its sleep becomes longer ${ }^{(26)}$. This phenomenon is more distinct in breastfed children and is partly due to the transfer with the mother's milk of hormones such as melatonin, which regulates the sleep and wake cycle in the immature infant body ${ }^{(27)}$. If we assume sleep deprivation to be the main cause of fatigue in women, sleep consolidation by melatonin in the infant could translate to a better sleep quality in the mother and account for a lower level of fatigue among breastfeeding women. Certainly, the level of fatigue in the mothers during that period also depends on many other factors than the feeding method.

\section{Kaiser Physical Activity Survey (KPAS)}

It is widely known that regular physical activity that is appropriate for a given individual provides invaluable health benefits, including metabolic and physical ones (in terms of body weight, muscle mass, strong bones and joints, and body shape), improvements in higher cognitive functions and immunomodulatory effects ${ }^{(28)}$. During early motherhood (up to 6 weeks after delivery), regardless of the feeding method, women are advised to return to their physical activity levels from before pregnancy, provided that there are no medical contraindications. Women who had medium levels of physical activity before becoming pregnant should undertake aerobic exercise for at least 150 minutes a week, which means moderate-intensity physical activity for at least 30 minutes five days a week or intensive aerobic exercise for at least 20 minutes three days a week ${ }^{(29)}$. In the present study, KPAS was also used to gather data on daily activities and family care. Unfortunately, only $3 \%$ of the respondents provided complete answers to all of the questions included in the 4 sections of KPAS. For this reason, the analysis included answers to questions in section I (household activities, taking care of family/household members) and section III (general level of physical activity including cycling, watching TV, walking for at least 15 minutes a day), i.e. sections that were answered in $100 \%$, and the final KPAS score did not differ significantly between the two study groups (there was no statistical significance). This means that the level of daily activity did not depend on the infant feeding method. Due to the lack of complete data from the remaining 2 sections, it was not possible to those of other authors. Apart from that, literature review shows that there are insufficient, if not scarce data regarding the physical activity of nursing mothers.

The current study also attempted to find relationships between scores on the 4 standardised scales. A high positive association $(r=0.62)$ with a high statistical significance ( $p=0.001)$ between the calculated indices of the FSS and PSS in the group of breastfeeding mothers indicates that fatigue and perceived stress reinforce each other. This can result in a decision to stop breastfeeding, since fatigue and stress are the most commonly provided reasons for this ${ }^{(30)}$. Considering this relationship, it is important to identify fatigue in breastfeeding mothers early in order for them to be able to receive support from family members and medical professionals such as lactation consultants, for example.

\section{CONCLUSIONS}

1. In breastfeeding mothers, fatigue and perceived stress reinforce each other. This relationship serves as an alarm signal to provide nursing mothers with optimal care in order to prevent them from stopping breastfeeding.

2. In a healthy population of mothers from 3 to 6 months postpartum, exclusively breastfeeding women are observed to have lower fatigue and sleepiness levels compared to those who decided to feed their children with formula only. These conclusions may be an additional source of information for the promotion of breastfeeding.

\section{Conflict of interest}

The authors do not report any financial or personal affiliations to persons or organisations that could adversely affect the content of or claim to have rights to this publication.

\section{References}

1. Wilson N, Wynter K, Fisher J et al.: Related but different: distinguishing postpartum depression and fatigue among women seeking help for unsettled infant behaviours. BMC Psychiatry 2018; 18: 309 .

2. Lewis BA, Gjerdingen D, Schuver K et al.: The effect of sleep pattern changes on postpartum depressive symptoms. BMC Womens Health 2018; 18: 12.

3. McGovern P, Dowd B, Gjerdingen D et al.: Mothers' health and work-related factors at 11 weeks postpartum. Ann Fam Med 2007; 5: 519-527.

4. Doan T, Gardiner A, Gay CL et al.: Breast-feeding increases sleep duration of new parents. J Perinat Neonatal Nurs 2007; 21: 200-206.

5. Mikoteit T, Brand S, Bürki N et al.: Breastfeeding is associated with increased Non REM S3-sleep in non-depressive mothers three months post partum. Pharmacopsychiatry 2015; 25 - A40.

6. Groër MW: Differences between exclusive breastfeeders, formula-feeders, and controls: a study of stress, mood, and endocrine variables. Biol Res Nurs 2005; 7: 106-117.

7. Alvarenga P, Frizzo GB: Stressful life events and women's mental health during pregnancy and postpartum period. Paidéia (Ribeirão Preto) 2017; 27: 51-59.

8. Krupp LB, Alvarez LA, LaRocca NG et al.: Fatigue in multiple sclerosis. Arch Neurol 1988; 45: 435-437. 
9. Valko PO, Bassetti CL, Bloch KE et al.: Validation of the fatigue severity scale in a Swiss cohort. Sleep 2008; 31: 1601-1607.

10. Johns MW: A new method for measuring daytime sleepiness: the Epworth sleepiness scale. Sleep 1991; 14: 540-545.

11. Cohen S, Kamarck T, Mermelstein R: A global measure of perceived stress. J Health Soc Behav 1983; 24: 385-396.

12. Sternfeld B, Ainsworth BE, Quesenberry CP: Physical activity patterns in a diverse population of women. Prev Med 1999; 28: 313-323.

13. Baecke JA, Burema J, Frijters JE: A short questionnaire for the measurement of habitual physical activity in epidemiological studies. Am J Clin Nutr 1982; 36: 936-942.

14. Senol DK, Yurdakul M, Ozkan SA: The effect of maternal fatigue on breastfeeding. Niger J Clin Pract 2019; 22: 1662-1668.

15. Pérez-Escamilla R, Buccini GS, Segura-Pérez S et al.: Perspective: should exclusive breastfeeding still be recommended for 6 months? Adv Nutr 2019; 10: 931-943.

16. Kramer MS, Kakuma R: The optimal duration of exclusive breastfeeding: a systematic review. World Health Organization, 2002. Available from: https://apps.who.int/iris/bitstream/handle/10665/67208/ WHO_NHD_01.08.pdf?ua=1 [cited: 25 October 2021].

17. Krol KM, Grossmann T: Psychological effects of breastfeeding on children and mothers. Bundesgesundheitsblatt Gesundheitsforschung Gesundheitsschutz 2018; 61: 977-985.

18. Hughes O, Mohamad MM, Doyle P et al.: The significance of breastfeeding on sleep patterns during the first 48 hours postpartum for first time mothers. J Obstet Gynaecol 2018; 38: 316-320.

19. Doan T, Gay CL, Kennedy HP et al.: Nighttime breastfeeding behavior is associated with more nocturnal sleep among firsttime mothers at one month postpartum. J Clin Sleep Med 2014; 10: 313-319.

20. Atas AN, Özerdoğan N: Perceived sleep quality and fatigue in a population of new mothers: a cross-sectional study comparing relationships with breastfeeding and bottle feeding. Breastfeed Med 2021. DOI: 10.1089/bfm.2021.0040.

21. Smith JP, Forrester RI: Association between breastfeeding and new mothers' sleep: a unique Australian time use study. Int Breastfeed J 2021; $16: 7$.

22. Mindell JA, Leichman ES, Composto J et al.: Development of infant and toddler sleep patterns: real-world data from a mobile application. J Sleep Res 2016; 25: 508-516.

23. Achermann P, Borbély AA: Mathematical models of sleep regulation. Front Biosci 2003; 8: 683-693.

24. Montgomery-Downs HE, Stremler R, Insana SP: Postpartum sleep in new mothers and fathers. Open Sleep J 2013; 6: 87-97.

25. Maehara $\mathrm{K}$, Mori E, Iwata $\mathrm{H}$ et al.: Postpartum maternal function and parenting stress: comparison by feeding methods. Int J Nurs Pract 2017; 23 Suppl 1.

26. Iwata S, Fujita F, Kinoshita $\mathrm{M}$ et al.: Dependence of nighttime sleep duration in one-month-old infants on alterations in natural and artificial photoperiod. Sci Rep 2017; 7: 44749.

27. Groër M, Davis M, Casey K et al.: Neuroendocrine and immune relationships in postpartum fatigue. MCN Am J Matern Child Nurs 2005; 30: 133-138.

28. Warburton DER, Bredin SSD: Health benefits of physical activity: a systematic review of current systematic reviews. Curr Opin Cardiol 2017; 32: 541-556.

29. Evenson KR, Mottola MF, Owe KM et al.: Summary of international guidelines for physical activity after pregnancy. Obstet Gynecol Surv 2014; 69: 407-414.

30. Huang P, Ren J, Liu Y et al.: Factors affecting breastfeeding adherence among Chinese mothers: a multicenter study. Medicine (Baltimore) 2017; 96: e7619. 